\title{
KANDUNGAN FITOKIMIA, POTENSI ANTIBAKTERI, DAN ANTIOKSIDAN HASIL EKSTRAKSI Caulerpa racemosa DENGAN PELARUT BERBEDA
}

\section{Phytochemical Content, Antibacterial, and Antioxidant Potency of Caulerpa racemosa Extracted with Different Solvents}

\author{
Endar Marraskuranto ${ }^{1 *}$, Muhammad Nursid ${ }^{1}$, Swestri Utami ${ }^{2}$, Iriani Setyaningsih ${ }^{2}$, \\ dan Kustiariyah Tarman ${ }^{2}$ \\ 'Balai Besar Riset Pengolahan Produk dan Bioteknologi Kelautan dan Perikanan, \\ JI. KS Tubun, Petamburan VI, Jakarta Pusat, DKI Jakarta, 10260 Indonesia \\ ${ }^{2}$ Departemen Teknologi Hasil Perairan, Fakultas Perikanan dan IImu Kelautan, Institut Pertanian Bogor, \\ Kampus IPB Darmaga, Jl. Agatis, Bogor, Jawa Barat, 16680 Indonesia \\ *Korespondensi Penulis: endar.marraskuranto@kkp.go.id
}

Diterima: 23 September 2020; Direvisi: 25 November 2020; Disetujui: 4 Februari 2021

\begin{abstract}
ABSTRAK
Caulerpa racemosa merupakan rumput laut hijau yang mengandung senyawa aktif yang berpotensi sebagai antibakteri dan antioksidan. Perbedaan profil fitokimia dan bioaktivitas suatu ekstrak dapat dipengaruhi oleh kepolaran pelarut ekstraksi. Penelitian ini bertujuan untuk mempelajari profil fitokimia, aktivitas antibakteri, dan antioksidan ekstrak C. racemosa. Ekstrak diperoleh dari sampel segar $C$. racemosa yang dimaserasi menggunakan pelarut $n$-heksana, etil asetat, dan metanol. Uji antibakteri dilakukan dengan metode Resazurin Microtitter Assay (REMA) terhadap bakteri Escherichia coli dan Staphylococcus aureus. Aktivitas antioksidan diuji menggunakan metode 1,1-diphenyl-2-picrylhydrazyl (DPPH) dan Ferric Reducing Antioxidant Power (FRAP). Hasil penapisan fitokimia memperlihatkan bahwa ekstrak $n$-heksana mengandung alkaloid dan triterpenoid, sedangkan ekstrak etil asetat dan metanol mengandung alkaloid, flavonoid, tanin, fenol, dan steroid. Aktivitas antibakteri terbaik ditunjukkan oleh ekstrak etil asetat dengan nilai Minimum Inhibitory Concentration (MIC) terhadap E. coli sebesar $250 \mu \mathrm{g} / \mathrm{mL}$. Ekstrak etil asetat $C$. racemosa juga memperlihatkan aktivitas antioksidan terbaik dengan nilai $\mathrm{IC}_{50}$ DPPH sebesar 110,7 $\mu \mathrm{g} / \mathrm{mL}$ dan nilai FRAP sebesar 96,68 $\mu \mathrm{mol}$ Fe (II)/g.
\end{abstract}

KATA KUNCI : Caulerpa racemosa, antibakteri, antioksidan, skrining fitokimia

\begin{abstract}
Caulerpa racemosa is a green seaweed that contains active compounds that are potential for antibacterial and antioxidant. The phytochemical constituents and bioactivity of an extract could depend on the extraction solvent polarity. This study aimed to determine the phytochemical profiles, antibacterial, and antioxidant activity of $\underline{C}$. racemosa extracts. Extracts were obtained from the fresh $\underline{C}$. racemosa samples that were macerated with $n$-hexane, ethyl acetate, and methanol. Antibacterial assay was tested by Resazurin Microtiter Assay (REMA) method against Escherichia coli and Staphylococcus aureus. Antioxidant activity was determined using 1,1-diphenyl-2-picrylhydrazyl (DPPH) and Ferric Reducing Antioxidant Power (FRAP) methods. Phytochemical screening showed that $n$-hexane extract contained alkaloid and triterpenoid, while ethyl acetate and methanol extracts contained alkaloids, flavonoids, tannins, phenols, and steroids. The most active extract in the antibacterial assay was ethyl acetate extract with a Minimum Inhibitory Concentration (MIC) value of $250 \mu \mathrm{g} / \mathrm{mL}$ against $\underline{E}$. coli. Ethyl acetate extract of $\underline{C}$. racemosa also showed the best antioxidant activity where the $I C_{50}$ of DPPH value was $110.7 \mu \mathrm{g} / \mathrm{mL}$ and the FRAP value was $96.68 \mu \mathrm{mol} \mathrm{Fe}(\mathrm{II}) / \mathrm{g}$.
\end{abstract}

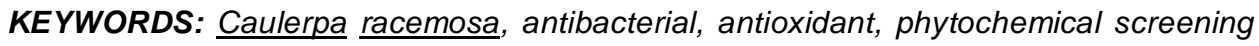

\section{PENDAHULUAN}

Caulerpa racemosa atau yang dikenal dengan anggur laut merupakan jenis rumput laut hijau yang dapat dikonsumsi dari kelompok Chlorophyceae. Rumput laut $C$. racemosa mengandung konstituen kimia seperti fenol, flavonoid, alkaloid, steroid (Rusli, Metusalach, Tahir, Salengke, \& Syamsuar, 2016), caulerpin, caulerpicin, dan caulerpenin (Felline, Caricato, Cutignano, Gorbi, \& Lionetto, 2012). Komponen bioaktif yang terkandung dalam $C$. racemosa tersebut berpotensi untuk dimanfaatkan 
sebagai bahan antioksidan dan antibakteri. Kandhasamy dan Arunachalam (2008) mengungkapkan aktivitas antibakteri ekstrak Caulerpa dengan spektrum luas terhadap bakteri patogen Gram negatif dan Gram positif. Selain sebagai antibakteri, C. racemosa diketahui dapat dimanfaatkan sebagai sumber antioksidan (Belkacemi, Belalia, Djendara, \& Bouhadda, 2020).

Salah satu informasi dasar yang diperlukan untuk memanfaatkan $C$. racemosa sebagai sumber senyawa antibakteri dan antioksidan adalah jenis pelarut yang digunakan untuk mengekstrak senyawa aktif yang ada di dalamnya. Ekstrak yang diperoleh dari pelarut dengan kepolaran berbeda dapat mengandung komponen aktif sesuai kelarutannya. Ekstrak etanol, etil asetat, dan $n$-heksana $C$. racemosa dilaporkan mengandung senyawa tanin, alkaloid, flavonoid, dan fenol dengan persentase yang berbeda (Marfuah, Dewi, \& Rianingsih, 2018).

Rumput laut $C$. racemosa banyak tersebar hampir di seluruh perairan pantai Indonesia, salah satunya Pantai Binuangeun, Kecamatan Wanassalam, Kabupaten Lebak, Banten. Rumput laut $C$. racemosa tumbuh pada zona pasang surut berupa rataan terumbu yang terhampar luas di Pantai Binuangeun. Profil metabolit $C$. caulerpa dari pantai Binunageun yang dipanen dengan cara yang berbeda telah diteliti oleh Sihono, Tarman, Maddupa, dan Januar (2018). Nursid et al. (2016) juga telah melakukan penapisan aktivitas antioksidan terhadap beberapa spesies rumput laut dari daerah ini.

Beberapa penelitian telah melaporkan aktivitas antibakteri dan antioksidan ekstrak rumput laut menggunakan berbagai jenis pelarut yang berbeda. Ekstrak $n$-heksana, kloroform, etil asetat, aseton, dan metanol dari C. chemnitzia menunjukkan penghambatan terhadap bakteri $E$. coli dengan zona hambat yang berbeda, yaitu masing-masing 10,1; 12,0; 12,8; 11,6; dan 10,3 mm (Raj, Chandrasekaran, Krishnamoorty, \& Venkatesalu, 2015). Penelitian lainnya mengungkapkan ekstrak $n$-heksana, kloroform, etil asetat, aseton, dan metanol dari $C$. scapelliformis memiliki kemampuan menghambat pertumbuhan bakteri $S$. aureus dengan zona hambat yang berbeda pula, yaitu masing-masing 13,0; 13,5; 15,5; 12,1; dan 10,8 mm (Jegan, Raj, Chandrasekaran, \& Venkatesalu, 2019). Ekstrak metanol C. racemosa memiliki diameter zona hambat terhadap bakteri Vibrio cholerae (Radhika, Veerabahu, \& Priya, 2012).

Ekstrak metanol C. rasemosa kering (dosis 4000 ppm) menunjukkan nilai FRAP rata-rata sebesar 46,5 $\mu \mathrm{mol} F e(\mathrm{II}) / \mathrm{g}$ dan penghambatan terhadap DPPH ratarata sebesar $31 \%$ (Djapiala, Lita, Montolalu, \& Mentang, 2013). Aktivitas antioksidan DPPH ekstrak
C. racemosa dari Pantai Sundak, Gunungkidul, Yogyakarta yang diekstraksi dengan pelarut $n$ heksana, etil asetat, dan metanol menunjukkan nilai $I_{50}$ berturut-turut 336,2 ppm; 180,2 ppm; dan 367,8 ppm (Kurniawan, Dewi, \& Agustini, 2012), dengan profil fitokima yang dihasilkan juga berbeda. Hal yang sama diungkap oleh Noor dan Nursandi (2015) dimana terdapat perbedaan profil fitokimia, rendemen, dan aktivitas antioksidan Caulerpasp. dari Teluk Lampung yang diekstraksi dengan $n$-heksana, etil asetat, dan metanol. Rumput laut Halimeda macrolobadilaporkan juga menghasilkan nilai IC $\mathrm{C}_{50}$ sebesar 259,34; 1567,27 dan $38,57 \mu \mathrm{g} / \mathrm{ml}$ setelah diekstraksi masing-masing dengan pelarut $n$-heksana, etil asetat, dan metanol (Muzaki, Setyati, Subagiyo, \& Pramesti, 2018).

Penelitian ekstraksi rumput laut $C$. racemosa dari Pantai Binuangeun, Banten menggunakan tiga jenis pelarut yang berbeda masih terbatas informasinya, demikian juga bioaktivitasnya, khususnya antibakteri dengan metode Resazurin Microtitter Assay (REMA) dan kapasitas antioksidan dengan metode Ferric Reducing Antioxidant Power (FRAP). Oleh karena itu, penelitian bioprospeksi $C$. racemosa dengan metode REMA dan FRAP dari wilayah tersebut penting untuk dilakukan. Penelitian ini dilakukan untuk mempelajari profil fitokimia dan bioaktivitas ekstrak $C$. racemosa yang diekstraksi dengan pelarut yang berbeda.

\section{BAHAN DAN METODE}

\section{Bahan}

Bahan yang digunakan dalam penelitian ini meliputi rumput laut hijau $C$. racemosayang diperoleh dari perairan Pantai Binuangeun, Banten. Bakteri uji E. coli $\left(\right.$ ATCC $\left.\AA 25922^{\mathrm{TM}}\right)$ dan $S$. aureus (ATCC ${ }^{8} 25923^{\mathrm{TM}}$ ) koleksi dari Laboratorium Bioteknologi, Balai Besar Riset Pengolahan Produk dan Bioteknologi Kelautan dan Perikanan (BBRPPBKP), pelarut $n$-heksana analitis (JT Baker), etil asetat analitis (JT Baker), metanol analitis (JT Baker), bahan uji antioksidan 1,1-diphenyl-2picrylhydrazyl (DPPH) (Sigma Aldrich) 2,4,6-tri(2piridil)-s-triazin (TPTZ) (Sigma Aldrich), dan resazurin (Sigma Aldrich).

\section{Metode}

\section{Pengambilan sampel dan ekstraksi}

Sampel diambil dari zona pasang surut Pantai Binuangen, Banten. Sampel yang diperoleh langsung dipreservasi di dalam cool box berisi es batu (15$20^{\circ} \mathrm{C}$ ). Identifikasi jenis berdasarkan karakteristik morfologi dilakukan menurut Atmadja, Kadi, Sulistijo dan Rachmaniar (1996) dan Setyobudiandi, Soekendarsi, Juariah, Bahtiar, dan Hari (2009). 
Proses identifikasi dilakukan di Laboratorium Hidrobiologi Laut, Fakultas Perikanan dan IImu Kelautan, Institut Pertanian Bogor.

Ekstraksi dilakukan dengan metode maserasi dengan rasio berat rumput laut terhadap volume pelarut 1:2 (b/v). Rumput laut dicuci sampai bersih, ditiriskan, ditimbang sebanyak $100 \mathrm{~g}$, dipotong kecil-kecil (sekitar 1-2 $\mathrm{cm}^{3}$ ), dan dimaserasi dengan pelarut berbeda, masing-masing dengan $200 \mathrm{ml} n$-heksana, etil asetat, atau metanol. Maserasi dilakukan selama 72 jam pada suhu ruang dan kondisi gelap. Filtrat yang diperoleh kemudian disaring menggunakan kertas saring Whatman no. 93. Evaporasi pelarut dilakukan dengan rotary vacuum evaporator (Buchi) dengan suhu penangas $40^{\circ} \mathrm{C}$ dan tekanan vakum berkisar antara 70-300 mbar. Ekstrak yang telah pekat kemudian dikeringkan menggunakan vacuum concentrator pada suhu ruang $33^{\circ} \mathrm{C}$ dan disimpan pada suhu $-20^{\circ} \mathrm{C}$ sebelum digunakan untuk penelitian selanjutnya.

\section{Analisis fitokimia ekstrak $C$. racemosa}

Analisis fitokimia yang dilakukan terhadap ekstrak C. racemosa meliputi deteksi senyawa alkaloid, flavonoid, tanin, dan steroid/triterpenoid yang mengacu pada Endarini (2016). Sedangkan analisis senyawa fenol dan saponin mengacu pada Harborne (1987).

\section{Uji aktivitas Antibakteri ekstrak C. racemosa}

Uji aktivitas antibakteri dilakukan dengan menentukan nilai Minimum Inhibition Concentration (MIC). Metode pengujian MIC yang digunakan yaitu Resazurin Microtitter Assay (REMA) sesuai Fajarningsih, Munifah, dan Zilda (2018). Bakteri $E$. coli dan $S$. aureus digunakan sebagai bakteri uji. Biakan bakteri uji diinokulasikan ke media Mueller Hinton Broth (MHB) dan ditumbuhkan dengan kondisi terkontrol pada suhu $37^{\circ} \mathrm{C}$ selama 24 jam. Bakteri uji yang telah tumbuh diencerkan hingga diperoleh kepadatan suspensi bakteri sesuai dengan standar McFarland 0,5 sebesar $10^{8} \mathrm{CFU} / \mathrm{mL}$ dengan nilai Optical Density (OD) 0,8-1,0 pada panjang gelombang $625 \mathrm{~nm}$. Pengujian dilakukan menggunakan mikroplate 96 sumuran steril. Sumuran pertama diisi larutan ekstrak dengan konsentrasi tertinggi yaitu 10 $\mathrm{mg} / \mathrm{mL}$ sebanyak $100 \mu \mathrm{L}$. Selanjutnya, pada ekstrak tersebut dilakukan pengenceran bertingkat ( $50 \mu \mathrm{L}$ akuades ditambah $50 \mu \mathrm{L}$ ekstrak) ke sumuran selanjutnya. Pengenceran dilakukan dalam satu baris mikroplate sampai dengan 11 kali pengenceran. Larutan reagen resazurin (Sigma Aldrich) sebanyak $10 \mu \mathrm{L}$ ditambahkan pada setiap sumuran. Suspensi bakteri $10 \mu \mathrm{L}\left(10^{8} \mathrm{CFU} / \mathrm{mL}\right)$ dalam media MHB $30 \mu \mathrm{L}$ ditambahkan pada tiap sumuran. Mikroplate diinkubasi dengan kondisi terkontrol pada suhu $37^{\circ} \mathrm{C}$ selama 24 jam. Kontrol positif (kloramfenikol) disiapkan dengan cara yang sama seperti sampel. Kontrol negatif disiapkan tanpa penambahan ekstrak. Pengamatan perubahan warna dilakukan secara visual, ekstrak yang aktif (dapat menekan pertumbuhan bakteri) akan menghasilkan warna biru pada sumuran, sedangkan ekstrak yang tidak aktif menghasilkan warna merah muda. Penentuan nilai MIC dilakukan berdasarkan penghambatan pertumbuhan bakteri pada konsentrasi paling rendah.

\section{Uji aktivitas antioksidan metode DPPH}

Uji aktivitas antioksidan dengan metode DPPH dilakukan menurut Sachindra et al. (2007) dengan beberapa modifikasi. Ekstrak kasar $C$. racemosa dibuat beberapa seri konsentrasi. Larutan sampel dimasukkan ke dalam sumuran masing-masing sebanyak $160 \mu \mathrm{L}$ untuk setiap seri konsentrasi. Selanjutnya, larutan DPPH (konsentrasi 0,76 mM) ditambahkan ke dalam sumuran yang berisi larutan sampel masing-masing sebanyak $40 \mu \mathrm{L}$. Kontrol sampel dibuat dengan mereaksikan larutan sampel sebanyak $160 \mu \mathrm{L}$ dan metanol sebanyak $40 \mu \mathrm{L}$ di dalam sumuran. Kontrol negatif dibuat dengan mereaksikan $160 \mu \mathrm{L}$ metanol dan $40 \mu \mathrm{L} \mathrm{DPPH}$, serta $200 \mu \mathrm{L}$ metanol digunakan sebagai blanko. Larutan asam askorbat (Merck) yang dibuat dalam beberapa seri konsentrasi digunakan sebagai kontrol positif. Microplate disimpan pada ruang gelap selama 30 menit dan suhu $27-28^{\circ} \mathrm{C}$. Absorbansi dari setiap sumuran dibaca dengan microplate reader Multiskan GO (Thermo) pada panjang gelombang $517 \mathrm{~nm}$. Penghambatan radikal bebas dinyatakan sebagai persentase penghambatan dan dihitung dengan rumus pada persamaan (1).

Hambatan $(\%)=\frac{(C-D)-(A-B)}{(C-D)}$

A adalah absorbansi ekstrak; B adalah absorbansi kontrol ekstrak; C adalah absorbansi kontrol negatif; dan $\mathrm{D}$ adalah absorbansi blanko. Selanjutnya, nilai Inhibition Concentration $50\left(\mathrm{IC}_{50}\right)$ ditentukan dari ekstrapolasi persentase penghambatan radikal bebas DPPH terhadap seri konsentrasi sampel. Nilai $I_{50}$ tersebut dihitung menggunakan analisis probit.

\section{Uji kapasitas antioksidan metode FRAP}

Uji aktivitas antioksidan dengan metode FRAP mengacu pada Benzie dan Strain (1996) dan Kelman et al. (2012). Reagen FRAP disiapkan dengan mencampurkan $300 \mathrm{mM}$ buffer asetat (pH 3,6), 10 $\mathrm{mM}$ larutan 2,4,6-tri(2-piridil)-s-triazin/TPTZ (Sigma Aldrich), dan $20 \mathrm{mM} \mathrm{FeCl}_{3} \cdot 6 \mathrm{H}_{2} \mathrm{O}$ dengan rasio 10:1:1 
$(\mathrm{v} / \mathrm{v})$. Reagen FRAP dibiarkan bereaksi pada suhu $37^{\circ} \mathrm{C}$ selama 1 menit. Larutan buffer asetat $(\mathrm{pH} 3,6)$ disiapkan dengan melarutkan $40,8 \mathrm{~g}$ natrium asetat trihidrat dalam $500 \mathrm{~mL}$ akuades dan $\mathrm{pH}$ larutan disesuaikan dengan penambahan asam asetat glasial. Larutan TPTZ disiapkan dengan mengencerkan TPTZ dalam $40 \mathrm{mM}$ larutan $\mathrm{HCl}$. Reagen FRAP sebanyak $150 \mu \mathrm{L}$ dituangkan ke mikroplate 96 sumuran dan ditambahkan dengan ekstrak $C$. racemosa (konsentrasi $1000 \mu \mathrm{g} / \mathrm{ml}$ ) sebanyak $20 \mu \mathrm{L}$. Mikroplate diinkubasi dalam keadaan gelap pada suhu $27-28^{\circ} \mathrm{C}$ selama 8 menit. Absorbansi diukur dengan pembacaan dari microplate reader Multiskan GO (Thermo) pada panjang gelombang $595 \mathrm{~nm}$. Untuk kurva standar, yang digunakan $\mathrm{FeSO}_{4} \cdot 7 \mathrm{H}_{2} \mathrm{O}$ dengan metode yang sama dengan sampel dengan konsentrasi 50, 100, 150, 200, 250, dan $300 \mu \mathrm{M}$. Kapasitas antioksidan ekstrak dihitung menggunakan persamaan yang dihasilkan dari kurva standar $\mathrm{FeSO}_{4} \cdot 7 \mathrm{H}_{2} \mathrm{O}$ dalam satuan $\mu \mathrm{mol} \mathrm{Fe}(\mathrm{II}) / \mathrm{g}$ ekstrak.

\section{Pengolahan data}

Setiap unit perlakuan dilakukan dengan 3 kali ulangan. Data tampilkan dalam bentuk rerata dan simpangan baku. Perbedaan tiap rerata dianalisis dengan uji ANOVA satu arah (signifikansi $5 \%$ ) yang dilanjutkan dengan uji beda nyata terkecil (Tukey). Analisis dilakukan dengan bantuan perangkat lunak MINITAB versi 15.0.
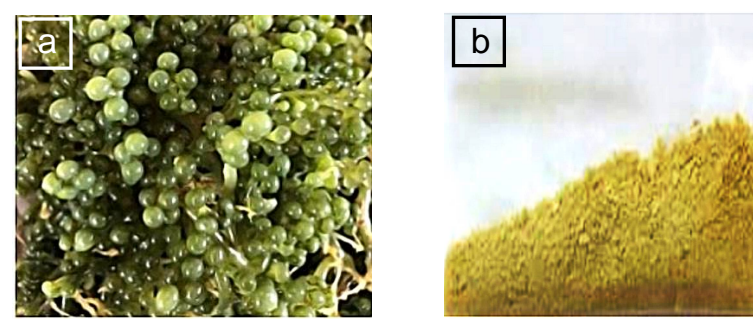

\section{HASIL DAN PEMBAHASAN}

\section{Karakterisasi Ekstrak}

Identitas sampel rumput laut hijau terkonfirmasi sebagai spesies $C$. racemosa melalui analisis morfologi di Laboratorium Hidrobiologi Laut, FPIK-IPB (Gambar 1a). Ekstrak $n$-heksana $C$. racemosa menghasilkan warna kuning kehijauan, sementara ekstrak etil asetat menghasilkan warna hijau muda, dan ekstrak metanol menghasilkan warna hijau tua (Gambar 1b-d). Rendemen masing-masing ekstrak $C$. racemosa dapat dilihat pada Tabel 1 . Ekstrak metanol merupakan ekstrak dengan rendemen tertinggi, yaitu $4,25 \%$, sementara rendemen terendah terdapat pada ekstrak $n$-heksana sebesar $1,22 \%(p<0,05)$.

Ekstraksi bertujuan untuk mendapatkan senyawa bioaktif target secara optimal dari suatu bahan atau material (Chang, Yang, Wen, \& Chern, 2002). Efisiensi ekstraksi sangat dipengaruhi oleh beberapa kondisi, antara lain metode ekstraksi, temperatur, waktu, komposisi fitokimia, dan pelarut yang digunakan. Jika kondisi ekstraksi tersebut sama, maka pelarut merupakan parameter yang paling penting dalam isolasi suatu senyawa aktif (Truong et al., 2019). Tingginya rendemen ekstrak metanol menunjukkan bahwa $C$. racemosa mengandung senyawa-senyawa polar dan semi polar yang dapat larut dengan baik dalam metanol. Polaritas pelarut sangat

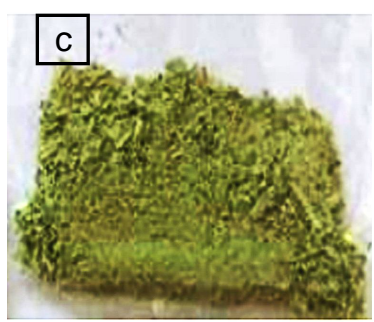

Gambar 1. Sampel rumput laut C. racemosa (a), dan hasil ekstrak $n$-heksana (b), etil asetat (c), dan metanol (d) C. racemosa

Figure 1. C. racemosa seaweed sample (a), and extracts of $n$-hexane (b), ethyl acetate (c) and methanol (d) of $\underline{\text {. }}$ racemosa

Tabel 1. Rendemen ekstrak $C$. racemosa yang diekstraksi dengan pelarut berbeda Table 1. Yield of $\underline{\text { C. }}$ racemosa extracts that were extracted with different solvent

\begin{tabular}{lc}
\hline \multicolumn{1}{c}{ Pelarut/Solvents } & Rendemen/Yield (\%) \\
\hline$n$-Heksana/n-Hexane & $1.22 \pm 0.33^{\mathrm{a}}$ \\
Etil asetat/Ethyl acetate & $2.08 \pm 0.29^{\mathrm{b}}$ \\
Metanol/Methanol & $4.25 \pm 0.24^{\mathrm{c}}$ \\
\hline
\end{tabular}

Keterangan/Notes : *) Huruf yang berbeda menunjukkan perbedaan nyata secara statistik pada $p<0,05 /$ ifferent letters indicate statistical differences at $p<0.05$ 
mempengaruhi jumlah bahan aktif yang dapat terekstrak. Metanol memiliki kisaran polaritas yang lebar sehingga dapat mengekstrak bahan aktif dalam jumlah yang lebih banyak, mulai dari senyawa non polar, semi polar sampai polar.

Sejumlah senyawa polar seperti gula, asam amino, dan glikosida (Houghton \& Raman, 1998), senyawa fenol dengan berat molekul rendah dan sedang serta senyawa-senyawa dengan polaritas medium (Lin, Kuo, Lin, \& Chiang, 2009), aglikon flavonoid (Dehkharghanian, Adenier, \& Vijayalakshmi, 2010), antosianin, terpenoid, saponin, tanin, xantoxilin, totarol, quacinoid, lakton, penon, dan polifenol larut di dalam metanol. Senyawa-senyawa alkaloid, aglikon, glikosida, sterol, terpenoid, dan flavonoid larut di dalam etil asetat (Cowan, 1999). N-heksana dapat melarutkan senyawa non polar seperti lemak, wax, aglikon, sterol, dan terpenoid (Cowan, 1999; Houghton \& Raman, 1998).

Penapisan fitokimia bertujuan memberikan informasi golongan senyawa yang terkandung pada C. racemosa. Ekstrak etil asetat dan metanol terlihat memiliki profil golongan senyawa yang sama. Perbandingan antara hasil uji fitokimia ekstrak $C$. racemosa dalam penelitian ini dengan penelitian lain dapat dilihat pada Tabel 2.

Profil fitokimia ekstrak $C$. racemosa memperlihatkan bahwa pada ekstrak $n$-heksana terdeteksi adanya golongan senyawa alkaloid dan triterpenoid, berbeda dengan ekstrak etil asetat dan metanol yang menunjukkan adanya golongan senyawa flavonoid, tanin, fenol, dan steroid. Berdasarkan profil fitokimia tersebut dapat diduga absennya salah satu atau kombinasi dari keempat golongan senyawa tersebut dapat menyebabkan bioaktivitas ekstrak $n$-heksana tidak sebaik ekstrak etil asetat dan metanol. Pada ekstrak metanol terdeteksi beberapa senyawa, antara lain alkaloid, flavonoid, tanin, fenol, dan steroid. Keberadaan flavonoid dan fenol pada ekstrak metanol sama dengan hasil yang diperoleh beberapa penelitian sebelumnya (Azhagu, Mala, \& Prakasam, 2015; Nurjanah, Jacoeb, Asmara, \& Hidayat, 2019) (Tabel 2). Perbedaan preparasi sampel dan metode maserasi diduga dapat mempengaruhi profil fitokimianya.

Penelitian Mehdinezhad, Ghannadi, dan Yegdaneh (2016) mengungkapkan adanya kandungan tanin, sterol, dan triterpenoid relatif tinggi pada profil fitokimia beberapa spesies rumput laut Sargassum. Tingginya aktivitas penangkapan radikal bebas pada rumput laut tersebut berhubungan dengan adanya gugus hidroksil senyawa fenolik. Selain itu, adanya senyawa fenol juga berhubungan dengan aktivitas antibakteri. Dalam penelitian ini, konstituen lain yang terkandung di dalam ekstrak etil asetat dan metanol adalah saponin dan steroid. Saponin dapat berperan sebagai anti inflamasi sedangkan steroid dapat dimanfaatkan sebagai agen antimikroba (Ambhore \& Whankatte, 2016).

\section{Aktivitas Antibakteri Ekstrak C. racemosa}

Ekstrak etil asetat memiliki nilai MIC yang paling kecil dibandingkan ekstrak $n$-heksana dan metanol yaitu sebesar $250 \mu \mathrm{g} / \mathrm{mL}$, baik terhadap bakteri $S$. aureus maupun E. coli (Tabel 3). Ekstrak $n$-heksana memiliki nilai MIC $1000 \mu \mathrm{g} / \mathrm{mL}$ terhadap kedua bakteri tersebut. Ekstrak metanol memiliki nilai MIC sebesar

Tabel 2. Komponen fitokimia ekstrak C. racemosa

Table 2. Phytochemical constituents of $\underline{C}$. racemosa extract

\begin{tabular}{|c|c|c|c|c|c|}
\hline \multirow[t]{2}{*}{ Uji/Test } & \multicolumn{3}{|c|}{ Ekstrak/Extract } & \multicolumn{2}{|c|}{$\begin{array}{l}\text { Hasil penelitian lain/ } \\
\text { Other research results }\end{array}$} \\
\hline & Hek & EA & $\mathbf{M}$ & $M^{(1)}$ & $M^{(2)}$ \\
\hline Alkaloid & + & + & + & - & - \\
\hline Flavonoid & - & + & + & + & + \\
\hline Tanin & - & + & + & - & + \\
\hline Saponin & - & - & - & + & + \\
\hline Fenol & - & + & + & + & + \\
\hline Triterpenoid & + & - & - & - & - \\
\hline Steroid & - & + & + & + & - \\
\hline
\end{tabular}

Keterangan/Notes : (+) : terdeteksi/detected; (-) : tidak terdeteksi/not detected; Hek : $n$-heksana/n-hexane; EA : etil asetat/ethyl acetate; $\mathrm{M}$ : metanol/methanol; $\mathrm{Cl}: \mathrm{khlorofom} /$ chloroform; ${ }^{(1)}$ : Nurjanah et al., (2019); (2): Azhagu et al. (2015). 
$250 \mu \mathrm{g} / \mathrm{mL}$ terhadap S. aureus dan $500 \mu \mathrm{g} / \mathrm{mL}$ terhadap E. coli.

Metode uji antibakteri REMA merupakan metode mikrodilusi yang menggunakan resazurin sebagai indikator warna untuk mengetahui penghambatan pertumbuhan bakteri. Perubahan warna karena reduksi resazurin (warna biru) menjadi resofurin (merah muda) disebabkan oleh enzim oksidoreduktase di dalam sel hidup (Sarker, Nahar \& Kumarasamy, 2007). Metode ini memiliki sensitivitas dan selektifitas yang lebih baik dibandingkan metode lain (Bwanga, Joloba, Haile, \& Hoffne, 2010). Aktivitas antibakteri diperoleh dengan menentukan nilai MIC. Nilai MIC didefinisikan sebagai konsentrasi terkecil dari suatu senyawa yang dapat menghambat pertumbuhan bakteri, sehingga semakin kecil nilai MIC maka aktivitas antibakteri semakin tinggi. Penggunaan metode REMA memungkinkan untuk menentukan konsentrasi ekstrak dalam satuan tertentu sehingga nilai hambatannya terhadap pertumbuhan bakteri dapat diketahui secara kuantitatif.

Hasil uji antibakteri menunjukkan bahwa ekstrak etil asetat memiliki bioaktivitas antibakteri terbaik dengan nilai MIC $250 \mu \mathrm{g} / \mathrm{mL}$ terhadap dua bakteri uji. Ekstrak metanol juga memperlihatkan bioaktivitas yang baik tetapi memiliki nilai MIC yang lebih tinggi yakni sebesar $500 \mu \mathrm{g} / \mathrm{mL}$ terhadap E. coli. Aktivitas antibakteri ekstrak $C$. racemosa masuk dalam kategori cukup potensial. Kategori ini mengacu pada Fajarningsih et al. (2018) yang menyatakan bahwa kategori tidak aktif apabila nilai MIC lebih dari 1000 $\mu \mathrm{g} / \mathrm{mL}$, kategori cukup potensial 100-1000 $\mu \mathrm{g} / \mathrm{mL}$, kategori potensial $10-100 \mu \mathrm{g} / \mathrm{mL}$, dan kategori sangat potensial apabila nilai MIC kurang dari $10 \mu \mathrm{g} / \mathrm{mL}$. Dalam penelitian ini, ekstrak etil asetat dan metanol C. racemosa memiliki aktivitas antibakteri tertinggi. Hasil berbeda justru diperoleh oleh Marfuah et al. (2018) yang memperlihatkan bahwa ekstrak etanol C. racemosa dari perairan Karimunjawa memiliki hambatan terbaik terhadap pertumbuhan bakteri $S$. aureus dan E. coli pada konsentrasi ekstrak 15\%.

Mengacu pada hasil penapisan fitokimia, ekstrak etil asetat dan metanol $C$. racemosa mengandung senyawa fenol dan tanin, sedangkan ekstrak $n$ heksana tidak mengandung kedua golongan senyawa tersebut. Penelitian Belkacemi et al. (2020) mendapatkan kandungan tanin dan fenol yang paling tinggi dalam ekstrak kloroform dibanding ekstrak $n$ heksana dan metanol. Seperti pada hasil penelitian ini, ekstrak $n$-heksana dan metanol memiliki aktivitas antibakteri lebih rendah daripada ekstrak etil asetat sehingga senyawa antibakteri yang terdapat dalam C. racemosa diduga berasal dari golongan fenol, saponin, ataupun steroid. Reguant, Bordons, Arola, dan Rozès (2000) menyatakan bahwa senyawa fenol memiliki efek penghambatan terhadap pertumbuhan mikroba. Tanin memiliki peran sebagai antivirus dan antibakteri. Sebagai tambahan, caulerpin, sebagai senyawa metabolit sekunder yang sudah banyak dikenal pada $C$. racemosa diduga berhubungan dengan aktivitas antibakteri. Caulerpin, suatu senyawa bisindol alkaloid, memiliki aktivitas antimikrobial khususnya sebagai agen antituberklosis (Chay, Cansino, Pinzón, Torres-Ochoa, \& Martínez, 2014).

\section{Aktivitas Antioksidan Metode DPPH}

Selaras dengan hasil uji antibakteri, ekstrak etil asetat memiliki aktivitas peredaman radikal bebas $\mathrm{DPPH}$ terbaik dengan nilai $\mathrm{IC}_{50}$ yang paling rendah $(\mathrm{p}<0,05)$. Ekstrak $n$-heksana adalah ekstrak yang paling tidak aktif diantara ekstrak etil asetat dan metanol (Gambar 2).

Nilai $I_{50}$ aktivitas peredaman radikal bebas DPPH ekstrak etil asetat $C$. racemosa diperoleh sebesar $110,7 \mu \mathrm{g} / \mathrm{mL}$. Nilai tersebut termasuk dalam kisaran aktivitas antioksidan medium. Aktivitas antioksidan ekstrak metanol $\left(\mathrm{IC}_{50}=132,08 \mu \mathrm{g} / \mathrm{mL}\right)$ juga termasuk dalam katagori medium, sedangkan aktivitas

Tabel 3. Nilai MIC ekstrak C. racemosa terhadap S. aureus dan E. coli

Table 3. MIC value of $\underline{C}$ racemosa extract againts $\underline{\underline{S}}$ aureus and $\underline{E}$. coli

\begin{tabular}{lcc}
\hline \multirow{2}{*}{ Ekstrak/Extracts } & \multicolumn{2}{c}{ Nilai MIC/MIC value $(\boldsymbol{\mu g} / \mathbf{m L})$} \\
\cline { 2 - 3 } & S. aureus & E. coli \\
\hline$n$-Heksana/n-Hexane & 1000 & 1000 \\
Etil asetat /Ethyl acetate & 250 & 250 \\
Metanol/Methanol & 250 & 500 \\
Kloramfenikol (kontrol positif)/ & 0.49 & 0.49 \\
Chloramphenicol (positive control) & & \\
\hline
\end{tabular}


antioksidan ekstrak $n$-heksana $\left(\mathrm{IC}_{50}=233,66 \mu \mathrm{g} / \mathrm{mL}\right)$ termasuk dalam katagori lemah. Menurut Molyneux (2004), aktivitas antioksidan suatu senyawa dapat dibagi dalam beberapa kategori, yaitu sangat kuat apabila nilai $\mathrm{IC}_{50}<50 \mu \mathrm{g} / \mathrm{mL}$, kuat $50-100 \mu \mathrm{g} / \mathrm{mL}$, medium $101-150 \mu \mathrm{g} / \mathrm{mL}$, dan lemah $>150 \mu \mathrm{g} / \mathrm{mL}$.

Penanganan rumput laut pasca pengambilan sampel mempengaruhi aktivitas penghambatan radikal bebas DPPH. Caulerpa yang dipreservasi dengan suhu dingin (penambahan es) memiliki aktivitas antioksidan terbaik dibanding dengan sampel yang dipreservasi dengan nitrogen cair dan disimpan dengan air laut (Sihono et al., 2018). Sementara itu, Nursid et al. (2016) mendapatkan aktivitas antioksidan C. caulerpa dengan metode FRAP berkisar antara 10,0-11,0 $\mu \mathrm{M} /$ $\mu \mathrm{g}$ ekstrak dan nilai inhibisi terhadap DPPH sebesar sekitar $15 \%$ pada konsentrasi ekstrak $1000 \mu \mathrm{g} / \mathrm{mL}$.

\section{Kapasitas Antioksidan Metode FRAP}

Nilai FRAP tertinggi terdapat pada ekstrak etil asetat, yaitu $96,68 \mu \mathrm{mol} F e(I I) / g$, diikuti oleh ekstrak metanol dan $n$-heksana dengan nilai FRAP berturutturut sebesar 71,82 $\mu \mathrm{mol} \mathrm{Fe(II)/g} \mathrm{dan} \mathrm{8,20} \mu \mathrm{mol} \mathrm{Fe(II)/}$ $g$ (Gambar 3). Nilai FRAP ketiga ekstrak C. racemosa berbeda secara signifikan $(p<0,05)$. Selaras dengan aktivitas peredaman radikal bebas DPPH, kapasitas antioksidan metode FRAP ekstrak etil asetat $(96,68$ $\mu \mathrm{mol} \mathrm{Fe}(\mathrm{II}) / \mathrm{g})$ dan metanol $(71,8 \mu \mathrm{mol} \mathrm{Fe}(\mathrm{II}) / \mathrm{g})$ juga termasuk dalam kategori medium. Kapasitas antioksidan ekstrak $n$-heksana $(8,20 \mu \mathrm{mol} \mathrm{Fe}(\mathrm{II}) / \mathrm{g})$ termasuk lemah. Jika suatu bahan atau ekstrak memiliki nilai kapasitas antioksidan $\geq 500 \mu \mathrm{mol} F e($ II)/ g, maka dikategorikan sebagai antioksidan sangat kuat, nilai kapasitas antara 100-500 $\mu \mathrm{mol} \mathrm{Fe(II)/g}$ termasuk kategori kuat, nilai kapasitas 10-100 $\mu \mathrm{mol}$

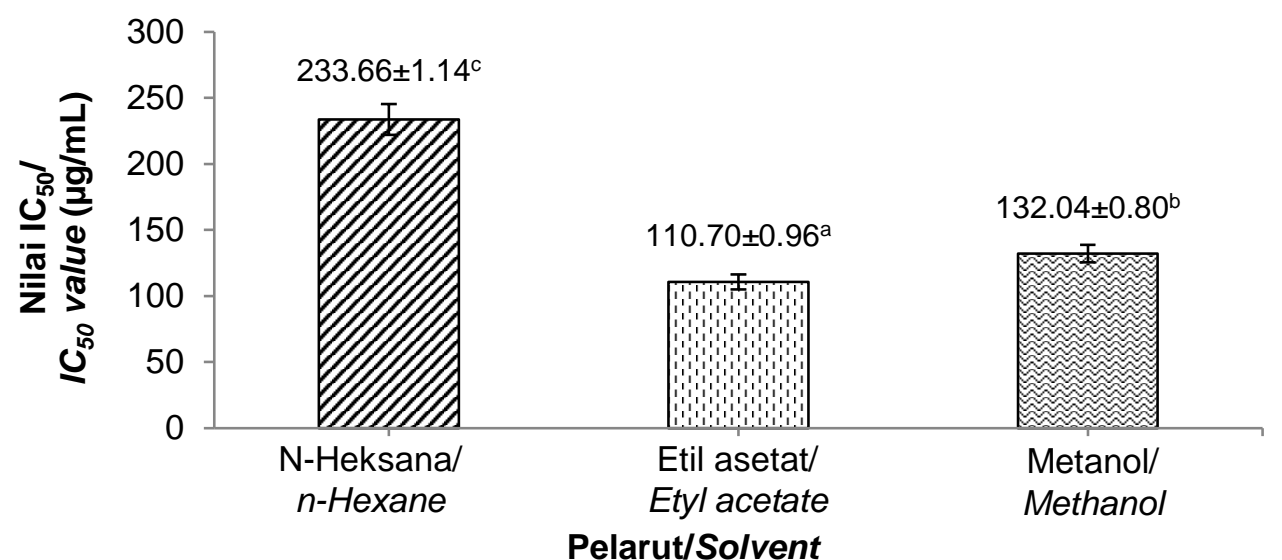

Keterangan/Notes : Huruf yang berbeda menunjukkan perbedaan nyata secara statistik pada $p<0,05 /$ Different letters indicate statistical differences at $p<0.05$

Gambar 2. Aktivitas penghambatan radikal bebas DPPH ekstrak $C$. racemosa Figure 2. DPPH free radical scavenging activity of $\underline{C}$. racemosa extract

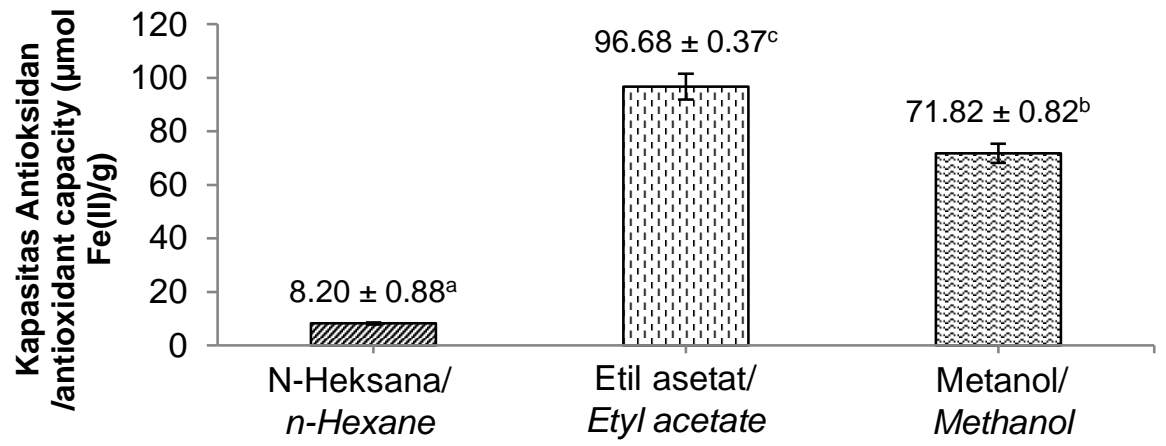

Pelarut/solvent

Keterangan/Notes: Huruf yang berbeda menunjukkan perbedaan nyata secara statistik pada $p<0,05 /$ different letters indicate statistical differences at $p<0.05$

Gambar 3. Kapasitas antioksidan FRAP ekstrak C. racemosa

Figure 3. FRAP antioxidant capacity of $\underline{\text { C. racemosa extract }}$ 
$\mathrm{Fe}(\mathrm{II}) / \mathrm{g}$ termasuk medium dan nilai kapasitas $\leq 10$ $\mu \mathrm{mol} \mathrm{Fe}(\mathrm{II}) / \mathrm{g}$ termasuk lemah (Wong, Li, Cheng, \& Chen, 2006). Keberadaan senyawa flavonoid pada sampel dapat membantu proses reduksi ion logam misalnya besi (Benavente, Castillo, Marin, Ortuño, \& Del-Rio, 1997). Oleh karena itu, keberadaan senyawa flavonoid pada ekstrak etil asetat menunjukkan efek positif pada hasil uji kapasitas antioksidan metode FRAP. Adanya komponen yang memiliki daya reduksi mengindikasikan bahwa komponen tersebut dapat bersifat sebagai pendonor elektron dan bisa mengurangi oksidasi lemak pada proses peroksidasi (Yen \& Chen, 1995).

Uji antioksidan metode DPPH dan FRAP termasuk uji yang didasarkan pada metode transfer elektron (electron transfer base assay atau ET-base assay). ET-base assay mengukur kapasitas antioksidan suatu bahan dengan mereduksi oksidan yang umumnya berubah warna pada saat tereduksi. Derajat perubahan warna tersebut berkorelasi dengan konsentrasi antioksidan pada suatu sampel (Apak, Ozyurek, Guc'lu, \& C'apanoglu, 2013). Uji aktivitas antioksidan dalam penghambatan radikal bebas DPPH didasarkan pada kemampuan suatu bahan atau ekstrak mendonorkan elektron atau atom hidrogen kepada radikal bebas $\mathrm{DPPH}$, sehingga akan terbentuk radikal bebas yang bersifat lebih stabil. FRAP merupakan uji kapasitas antioksidan yang mengukur kemampuan antioksidan suatu bahan mendonorkan elektron, sehingga terjadi reaksi reduksi kompleks Fe (III)tripiridiltriazin (TPTZ) yang tidak berwarna menjadi kompleks Fe (II)-TPTZ yang berwarna biru pada pH rendah (Pisoschi \& Negulescu, 2011). Reaksi FRAP dengan antioksidan yang menghasilkan warna tunggal, yaitu Fe (II)-TPTZ diamati secara spektrofotometri, dimana absorbansi FRAP versus kurva konsentrasi memiliki linieritas yang baik. Kekurangan metode FRAP adalah kurang sensitif dalam mendeteksi kapasitas antioksidan protein yang mengandung tiol, resveratrol dan karotenoid (Pulido, Bravo, \& SauraCalixto, 2000).

Uji DPPH dan FRAP termasuk metode yang relatif sederhana, praktis, dan relatif tidak mahal dalam mengevaluasi aktivitas penghambatan radikal bebas suatu antioksidan (Kedare \& Singh, 2011). Apak et al. (2013) mempertegas bahwa tidak ada uji antioksidan lain yang lebih sederhana dan murah dibandingkan dengan metode DPPH. Secara keseluruhan, hasil penelitian ini memperlihatkan potensi antibakteri dan antioksidan rumput laut $C$. racemosa serta pendugaan konstituen fitokimia yang ada di dalamnya. Meskipun aktivitas ekstrak $C$. racemosa termasuk dalam kategori medium, tetapi hasil penelitian ini dapat digunakan untuk menambah informasi dan sebagai bahan pertimbangan dalam pengembangan bahan aktif yang terdapat pada $C$. racemosa sebagai ingredient nutraseutika, kosmetika, maupun farmaseutika.

\section{KESIMPULAN}

Ekstrak yang diperoleh dari pelarut dengan kepolaran berbeda memberikan pengaruh terhadap senyawa aktif yang dihasilkan dari $C$. racemosa. Perbedaan kepolaran pelarut yang digunakan berpengaruh pada rendemen, aktivitas antibakteri, dan antioksidan masing-masing ekstrak. Walaupun memiliki rendemen yang lebih rendah daripada hasil ekstraksi dengan metanol, ekstrak etil asetat $C$. racemosa yang terdeteksi mengandung alkaloid, flavonoid, tanin, fenol, dan steroid merupakan ekstrak yang menghasilkan aktivitas antibakteri dan antioksidan terbaik.

\section{DAFTAR PUSTAKA}

Ambhore, J. S. \& Whankatte, V. R. (2016). Biodiversity of marine algae along the Raigad Coast of Konkan, Maharashtra. European Journal Experimantal Biology, 6(4), 69-76.

Apak R, Ozyurek M, Guc'lu K, \& C'apanoglu, E. (2013). Antioxidant activity/capacity measurement 1. Classification, physicochemical principles, mechanisms, and electron transfer (ET)-based assays. Journal of Agricultural \& Food Chemistry, 64(5), 997-1027.

Atmadja, W. S., Kadi, A., Sulistijo, \& Satari, R. (1996). Pengenalan jenis-jenis rumput laut Indonesia. Puslitbang Oseanologi, LIPI, Jakarta.

Azhagu, R. R., Mala, K., \& Prakasam, A. (2015). Phytochemical analysis of marine macroalga Caulerpa racemosa (J. Agardh) (Chlorophyta Caulerpales) from Tirunelveli District, Tamilnadu, India. Journal of Global Biosciences, 4(8), 3055-3067.

Belkacemi, L., Belalia, M., Djendara, A. C., \& Bouhadda, Y. (2020). Antioxidant and antibacterial activities and identification of bioactive compounds of various extracts of Caulerpa racemosa from Algerian coast. Asian Pacific Journal of Tropical Biomedicine, 10(2), 87-94. doi: 10.4103/2221-1691.275423

Benavente, G. O., Castillo, J., Marin, F. R., Ortuño, A., \& Del-Rio, J. A. (1997). Uses and properties of citrus flavonoids. Journal Agricultural Food Chemistry, 45(1),4505-4515. doi: 10.1021/jf970373s

Benzie, I. F. F. \& Strain, J. J. (1996). The ferric reducing ability of plasma (FRAP) as a measure of "antioxidant power": the FRAP assay. Analytical Biochemistry, 239 (1), 70-76. doi: 10.1006/abio.1996.0292.

Bwanga, F., Joloba, M. L., Haile, M., \& Hoffne, S. (2010). Evaluation of seven tests for the rapid detection of multidrug-resistant tuberculosis in Uganda. The International Journal of Tuberculosis and Lung Disease, 14(7),890-895. 
Chang, C., Yang, M., Wen, H., and Chern, J. (2002). Estimation of total flavonoid content in propolis by two complementary colorimetric methods. Journal of Food and Drug Analysis, 10(3),178-182.

Chay, C. I .C., Cansino, R. G., Pinzón, C. I. E., TorresOchoa, R. O., \& Martínez, R. (2014). Synthesis and anti-tuberculosis activity of the marine natural product caulerpin and its analogues. Marine Drugs, 12(4), 1757-1772. doi:10.3390/md12041757

Cowan, M.M. (1999). Plant product as antimicrobial agents. Journal of Microbiology Reviews, 12(4), 564582.

Dehkharghanian, M., Adenier, H., \& Vijayalakshmi, M. A. (2010). Study of flavonoids in aqueous spinach extract using positive electrospray ionization tandem quadrupole mass spectrometry. Food Chemistry, 121(3), 863-870. doi : 10.1016/j.foodchem.2010.01.007

Djapiala, F. Y., Montolalu, L. A. D. Y., \& Mentang F. (2013). Kandungan total fenol dalam rumput laut Caulerpa racemosa yang berpotensi sebagai antioksidan. Jurnal Media Teknologi Hasil Perikanan, 1(2), 1-5. doi: https://doi.org/10.35800/mthp.1.2.2013.1859

Endarini, L.H. (2016). Farmakognisi dan Fitokimia. Pusdik SDM Kesehatan Badan Pengembangan dan Pemberdayaan Sumberdaya Manusia Kesehatan, Kementarian Kesehatan Republik Indonesia, Jakarta. (pp. 130-134). Diakses dari: http:// bppsdmk.kemkes.go.id/pusdiksdmk/wp-content/ uploads/2017/08/Farmakognisi-dan-FitokimiaKomprehensif.pdf tanggal 23 September 2020.

Fajarningsih, N. D., Munifah, I., \& Zilda, D. S. (2018). Evaluation of antibacterial assays for screening of marine invertebrate extracts. Squalen Bulletin of Marine and Fisheries Postharvest and Biotechnology, 13(1),1-8. doi: 10.15578/squalen.v13i1.294

Felline, S., Caricato, R., Cutignano, A., Gorbi, S., \& Lionetto, M. G. (2012). Subtle effects of biological invasions: cellular and physiological responses of fish eating the exotic pest Caulerpa racemosa. PLOS ONE, 7(6), e38763. doi: 10.1371/journal.pone.0038763

Harborne, J. B. (1987). Metode fitokimia, penuntun cara modern menganalisis tumbuhan. (pp 1-2, 147-151, 234-236). Terjemahan: Padmawinata K, Sudiro I. Bandung (ID): Institut Teknologi Bandung.

Houghton, P., \& Raman, A. (1998). Laboratory handbook for the fractionation of natural extracts (pp.199). New York : Chapman and Hall.

Januar, H. I. \& Wikanta, T. (2011). Korelasi kandungan fukosantin dari Turbinaria sp. terhadap nutrien laut di Pantai Binuangeun dan Krakal. Squalen Bulletin of Marine and Fisheries Postharvest and Biotechnology, 6(1), 18-25. doi: 10.15578/ squalen.v6i1.57

Jegan, S., Raj, G. A., Chandrasekaran, M., \& Venkatesalu, V. (2019). Anti-MRSA activity of Caulerpa and Ulva species from Gulf of Mannar Coast, South India. Journal of Emerging Technologies and Innovative Research, 6(1), 78-99.

Kandhasamy, M. \& Arunachalam, K. D. (2008). Evaluation of in vitro antibacterial property of seaweeds of southeast coast of India. African Journal of Biotechnology, 7(12), 1958-1961. doi: 10.5897/ AJB08.120.

Kedare, S. B. \& Singh, R. P. (2011). Genesis and development of DPPH method of antioxidant assay. Journal of Food Sciences \& Technology, 8(4), 412422. doi: 10.1007/s13197-011-0251-1

Kelman, D., Posner, E. K., McDermid, K. J., Tabandera, N. K., Wright, P. R., \& Wright, A. D. (2012). Antioxidant activity of Hawaiian marine algae. Marine Drugs, 10(2), 403-416. doi: 10.3390/md10020403

Kusumawati, R., Basmal, J., \& Utomo, S.B. (2018). Physicochemical characteristics of sodium alginate extracted from Turbinaria sp. and Sargassum sp. Squalen Bulletin of Marine and Fisheries Postharvest and Biotechnology, 13(2), 79-84. doi: 10.15578/ squalen.v13i2.297

Kurniawan, A., Dewi, E. N., \& Agustin, T. W. (2012). Kajian potensi aktivitas antioksidan rumput laut Caulerpa racemosa dari Pantai Sundak Kabupaten Gunungkidul. Prosiding Seminar Nasional Bioteknologi Kelautan dan Perikanan 2012, Balai Besar Riset Pengolahan Produk dan Bioteknologi Kelautan dan Perikanan, 310-322.

Lin, H.Y., Kuo, Y.H., Lin, Y.L., \& Chiang W. (2019). Antioxidative effect and active component from leaves of lotus (Nelumbo nucifera). Journal of Agricultural and Food Chemistry, 57(15), 6623-6629. doi: 10.1021/jf900950z

Marfuah, I., Dewi, E. N., \& Rianingsih, L. (2018). Kajian potensi ekstrak anggur laut (Caulerpa racemosa) sebagai antibakteri terhadap bakteri Escherichia coli dan Staphylococcus aureus. Jurnal Pengolahan dan Bioteknologi Hasil Perikanan, 7(1), 7-14.

Mehdinezhad, N., Ghannadi, A., \& Yegdaneh, A. (2016). Phytochemical and biological evaluation of some Sargassum species from Persian Gulf. Research in Pharmaceutical Sciences, 11(3), 243-249.

Molyneux, P. (2004). The use of stable free radical diphenylpicrilhydrazyl (DPPH) for estimating antioxidant activity. Journal Science Technology, 26(2), 211-219.

Muzaki, A. F., Setyati, W. A., Subagiyo, \& Pramesti, R. (2018). Aktivitas antioksidan ekstrak rumput laut Halimeda macroloba dari Pantai Teluk Awur, Jepara, Jawa Tengah. Jurnal Enggano, 3(2), 144-155. doi: 10.31186/jenggano.3.2.144-155

Noor, N. M. \& Nursandi, J. (2014). Karakteristik kimiawi rumput laut lokal (Caulerpa sp.) dan potensinya sebagai sumber antioksidan. Prosiding Seminar Nasional Pengembangan Teknologi Pertanian. Politeknik Negeri Lampung 24 Mei 2014, 577-584.

Nurjanah, Jacoeb, A.M., Asmara, D.A., \& Hidayat, T. (2019). Phenolic compound of fresh and boiled sea grapes (Caulerpa sp.) from Tual, Maluku. Food Science and Technology Journal, 1(1), 31-39, doi: $: 10.33512 /$ fsj.v1i1.6244

Nursid, M., Wikanta, T., \& Susilowati. (2013). Aktivitas antioksidan, sitotoksisitas dan kandungan fukosantin ekstrak rumput laut coklat dari Pantai 
Binuangeun, Banten. Jurnal Pascapanen dan Bioteknologi Kelautan dan Perikanan, 8(1), 73-84. doi: 10.15578/jpbkp.v8i1.55

Nursid, M., Marraskuranto, E., Atmojo, K.B., Hartono, T. M. P., Meinita, M. D. N., \& Riyanti. (2016). Investigation on antioxidant compounds from marine algae extracts collected from Binuangeun Coast, Banten, Indonesia. Squalen Bulletin of Marine and Fisheries Postharvest and Biotechnology, 11(2), 59-67. doi : 10.15578/squalen.v11i2.243

Pisoschi, A. M. \& Negulescu, G. P. (2011). Methods for total antioxidant activity determination: a review. Biochemistry and Analytical Biochemistry, 1(1), 1-10. doi: 10.4172/2161-1009.1000106

Pulido, R., Bravo, L., \& Saura-Calixto, F. (2000). Antioxidant activity of dietary polyphenols as determined by a modified ferric reducing/antioxidant power assay. Journal of Agricultural \& Food Chemistry, 48(8), 3396"3402. doi: 10.1021/jf9913458

Radhika, D., Veerabahu, C., \& Priya, R. (2012). Antibacterial activity of some selected seaweeds from the gulf of Mannar Coast, South India. Asian Journal of Pharmaceutical and Clinical Research, 5(4), 89-90.

Raj, G. A., Chandrasekaran, M., Krishnamoorty, S., \& Venkatesalu, V. (2015). Antibacterial activity of diff erent solvent extracts of Caulerpa chemnitzia (Esper) J.V. Lamououx from Mandapam, Gulf of Mannar Southeast Coast, Tamil Nadu, India. Journal of Medicinal Herbs and Ethnomedicine, 1(1), 24-31.

Reguant, C., Bordons, A., Arola, L., \& Rozès N. (2000). Influence of phenolic compounds on the physiology of Oenococcus oeni from wine. Journal of Applied Microbiology, 88(6), 1065-1071. doi: 10.1046/j.13652672.2000.01075

Rusli, A., Metusalach, M., Tahir, M.M., Salengke \& Syamsuar. (2016). Analysis of bioactive compounds of Caulerpa recemosa, Sargassum sp. and
Gracillaria verrucosa using different solvents. Jurnal Teknologi, 78(4-2), 15-19. doi: 10.11113/jt.v78.8146

Sachindra, N. M., Sato, E., Maeda, H., Hosokawa, M., Niwano, Y., Kohno., \& Miyashita, K. (2007). Radical scavenging and singlet oxygen quenching activity of marine carotenoid fucoxanthin and its metabolites. Journal of Agricultural Food \& Chemistry, 55(21), 8516-8522. doi: 10.1021/jf071848a

Sarker, S.D., Nahar, L., \& Kumarasamy, Y. (2007). Microtitre plate-based antibacterial assay incorporating resazurin as an indicator of cell growth, and its application in the in vitro antibacterial screening of phytochemicals. Methods, 42(4), 321 324. doi: 10.1016/j.ymeth.2007.01.006

Setyobudiandi, I., Soekendarsi, E., Juariah, U., Bahtiar \& Hari, H. (2009). Seri biota laut, rumput laut Indonesia, Jenis dan upaya pemanfaatan. Kendari: UNHALU Press.

Sihono, Tarman, K., Maddupa, H., \& Januar, H.I. (2018). Metabolite profiles and antioxidant activity of Caulerpa racemosa with different handlings. Squalen Bulletin of Marine and Fisheries Postharvest and Biotechnology, 13(3), 93-100. doi: 10.15578/ squalen.v13i3.355

Truong, D. H., Nyuyen, D. H., Anh, N. T., Bui, A. V., Do, T. H., \& Nguyen, H. C. (2010). Evaluation of the use of different solvents for phytochemical constituents, antioxidants, and in vitro anti-inflammatory activities of Severinia buxifolia. Journal of Food Quality, 2019. doi: 10.1155/ 2019/8178294

Wong, C. C., Li, H. B., Cheng, K. W., \& Chen, F. (2006). A systematic survey of antioxidant activity of 30 Chinese medicinal plants using the ferric reducing antioxidant power assay. Food Chemistry, 97, 705-711. doi: 10.1016/j.foodchem.2005.05.049

Yen, G. C., \& Chen, H.Y. (1995). Antioxidant activity of various tea extracts in relation to their antimutagenicity. Journal Agricultural Food Chemistry, 43(1), 27-32. 